\title{
Influence of Cross-Inoculation on Groundnut and Bambara Groundnut-Rhizobium Symbiosis: Contribution to Plant Growth and Yield in the Field at Sarh (Chad) and Ngaoundere (Cameroon)
}

\author{
Doloum Gomoung1,3, Mbaiguinam Mbailao², Steve Takoukam Toukam³, Albert Ngakou ${ }^{*}$ \\ ${ }^{1}$ Department of Biology and Geology, Faculty of Science and Technology, University of Sarh, Sarh, Chad \\ ${ }^{2}$ Laboratory Research Laboratory on Natural Substances, University of N'Djamena, N'Djamena, Chad \\ ${ }^{3}$ Department of Biology Sciences, Faculty of Science, University of Ngaoundere, Ngaoundere, Cameroon \\ Email: *alngakou@yahoo.fr
}

How to cite this paper: Gomoung, D., Mbailao, M., Toukam, T.S. and Ngakou, A. (2017) Influence of Cross-Inoculation on Groundnut and Bambara Groundnut-Rhizobium Symbiosis: Contribution to Plant Growth and Yield in the Field at Sarh (Chad) and Ngaoundere (Cameroon). American Journal of Plant Sciences, 8, 19531966.

https://doi.org/10.4236/ajps.2017.88131

Received: June 13, 2017

Accepted: July 25, 2017

Published: July 28, 2017

Copyright $\odot 2017$ by authors and Scientific Research Publishing Inc. This work is licensed under the Creative Commons Attribution International License (CC BY 4.0).

http://creativecommons.org/licenses/by/4.0/

\begin{abstract}
In the context of sustainable research aiming at improving seed yield and maintaining soil fertility, a study on cross-inoculation of groundnut (Arachis hypogaea L.) and Bambara groundnut (Vigna subterranea (L.) Verd.) with rhizobia strains from four crop legumes was carried out at Sarh (Chad) and Ngaoundere (Cameroon). The experiment was conducted in each site following a randomized complete block design with 6 treatments known as the control, and 5 cross-inoculation formulations (RA, RN, RS, RV and MR), each of which was replicated thrice. Results obtained show that cross-inoculation contributed to the improvement of growth (plant sizes and biomasses) of the two crop legumes, as well as their seed yield at harvest. The enhanced yield expressed in $\mathrm{kg} / \mathrm{ha}$ varied from $9.83 \%$ to $63.73 \%$ for groundnut and $72.71 \%$ for Bambara groundnut. These findings suggest that groundnut and Bambara groundnut do have a symbiotic affinity with rhizobia from other crop legumes. Whereas Groundnut, Cowpea, Soybean, Bambara groundnut rhizobia (GR, $\mathrm{CR}, \mathrm{SR}, \mathrm{BR}$ ) alone, and the fourth in a mixture (RM) could be used to help improving groundnut seed yields; this mixture would not be indicated for intensive cultivation of Bambara groundnut later.
\end{abstract}

\section{Keywords}

Bambara Groundnut, Groundnut, Growth, Rhizobia, Cross-Inoculation, Yield, Chad, Cameroon 


\section{Introduction}

In sub-Saharan Africa, particularly in the Sudano-Guinean savannahs, soils are generally depleted in nitrogen and organic matter by cash crops such as cotton. In these soils, crop production is limited by the lack of nitrogen and other mineral elements available to the plant (Bado [1]). Population growth considerably reduces the area of arable land (Freeman et al. [2]). All these phenomena create an imbalance between the quantity of agricultural products available and the food needs of the population on the one hand, and environmental management on the other. This implies that the population does not have enough to eat, therefore does not have a healthy and balanced life (Cooke [3]).

Under these conditions, growers manage to enhance their crop yields through the use of chemical inputs that are costly, and potentially are polluting human and its environment (Acosta et al. [4]). In developing countries such as Chad and Cameroon, cereal crops are the basis of diet, although its nutritional quality is deficient in protein (Tien et al. [5]; Watier [6]). This lack of protein has stimulated the search for new sources of protein that can supplement or substitute existing proteins (Ahmet and Abdallah [7]).

To address this issue of food insecurity, soil infertility and environmental pollution, several cropping techniques such as crop rotation and intercropping (Gandebe et al. [8]; Useni et al. [9]), and nowdays, the use of organic fertilizers (Ngakou et al. [10]; Ridine et al. [11]), microbial biofertilizers such as rhizobia and mycorrhiza (Ngakou et al. [12] [13] [14]) have been prioritized and applied. No research has yet been carried out to look particularly at the cross-inoculation Rhizobium-legume symbiosis in the Guinea and Sudano-savannahs. It is in this context that this research was designed to evaluate the effect of cross-inoculation with legume-nodulating Rhizobium on productivity of Bambara groundnut, groundnut commonly grown in Cameroon and Chad.

\section{Materials and Methods}

\subsection{Experimental Sites Data}

The experimental field sites were located at the University of Sarh in southern Chad $\left(09^{\circ} 04.51^{\prime} \mathrm{N}, 18^{\circ} 25.22^{\prime} \mathrm{E}\right.$, at $375 \mathrm{~m}$ elevation), while in Cameroon, it was established within the University campus $\left(07^{\circ} 24.61^{\prime} \mathrm{N}, 13^{\circ} 34.24^{\prime} \mathrm{E}\right.$, at $1155.8 \mathrm{~m}$ elevation). Trials were carried out during the cropping season extending from October 2015 to Febuary 2016 at Sarh-Chad (temperature: $25^{\circ} \mathrm{C}-39^{\circ} \mathrm{C}$, rainfall: $800-1200 \mathrm{~mm} /$ year), and from March to July 2015 at Ngaoundere-Cameroon (temperature: $22^{\circ} \mathrm{C}-28^{\circ} \mathrm{C}$, rainfall: $1500-2500 \mathrm{~mm} /$ year).

\subsection{Biological Materials}

Groundnut (Arachis hypogaea L.), a flower variety 11 provided by the Chadian Institute for Agricultural Research and Development (ITRAD) of Bebedja in Chad, has a life cycle of about 90 days. It is a plant with yellow flowers, pinnate leaves that give at maturity two or very rarely three seeds per pod. Some pods may have only a single seed. Bambara groundnut (Vigna subterranea (L.) Verd.), 
commonly known as voandzou was a local Djar variety, also supplied by ITRAD. It has 90 to 100 days at maturity, with seeds having beige black hile outline. Flowers are yellow in colour, leaves are trifoliolate, while pods give at maturity one, but very rarely two seeds. Rhizobium strains were produced as liquid inoculum from groundnut, Bambara groundnut cowpea, and soybean root nodules at the microbiology laboratory of the Institute for Agricultural Research and Development (IRAD) at Wakwa, Ngaoundere in Cameroon.

\subsection{Evaluation of the Physico-Chemical Soil Parameters}

Soils were sampled before sowing and after harvest. Physico-chemical analysis of soils was carried out following AFNOR method [15] at the Chadian Institute for Agronomic Research and Development (ITRAD) laboratory of N'Djamena.

\subsection{Experimental Field and Treatments}

The laboratory-adapted experimental set-up consisted of 2 randomized complete block fields, one field per legume crop species. Each block has 6 plots randomly arranged according to different treatments: control (Ctrl), Groundnut rhizobia (GR), Cowpea (CR), soybean rhizobia (SR), Bambara groundnut rhizobia (BR), and the Mixture of rhizobia (MR) from the 4 legume crop species. These six treatments were replicated uniformly in the three blocks numbered I, II, III, for a total of 18 plots per field trial. The experimental unit was a rectangular plan of (3 $\times 2) \mathrm{m}^{2}$. Plots were separated $0.50 \mathrm{~m}$ apart, while blocks were separated by a distance of $1 \mathrm{~m}$.

\subsection{Sowing and Seed Inoculation}

Control plots were sown first. Each plot had 7 lines with 9 sowing holes each, giving a total of 63 plants per plot. The sowing interval between plants was 25 $\mathrm{cm}$, and $30 \mathrm{~cm}$ between lines (Ngakou et al. [14]). The distance between the outer lines and the plot edges was about $25 \mathrm{~cm}$. For each cross-inoculation formulation, seeds were coated with $100 \mathrm{ml}$ of liquid inoculum solution, and $25 \mathrm{~g}$ of Nido milk serving as adhesive carrier. Different treatments were applied to seeds at sowing time. Weeding was done on the 12, 26 and 45 DAP with hoes and hands, while adding soften soil around each plant to avoid exposure of pods out of the soil surface.

\subsection{Evaluation of Plant Growth and Yield Parameters}

The plant size was measured from the crown to the last leaf at 30 and 60 DAP on 30 randomly selected plants per treatment (Zakaria [16]). These measurements were performed early in the morning before 8 a.m. to avoid wind disturbances. Plants were dried at $65^{\circ} \mathrm{C}$ in a P-Selecta oven $\left(0^{\circ} \mathrm{C}\right.$ to $\left.250^{\circ} \mathrm{C}\right)$ for 48 hours and then, weighed using a Gilbertini brand scale at $0.001 \mathrm{~g}$ sensitivity as previously reported (Ngakou et al. [12]).

\subsubsection{Assessment of the Number and Dry Weight of Pods}

Pods were harvested from 30 randomly selected plants per treatment. All pods 
harvested from the same plant were manually counted and stored into a labeled envelope. Groundnut and Bambara groundnut pods were dried at $65^{\circ} \mathrm{C}$ for $48 \mathrm{~h}$ in the oven and weighed using a Gilbertini scale at $0.001 \mathrm{~g}$ sensitivity.

\subsubsection{Determination of Seed Yield $\left(\mathrm{Kg} \mathrm{ha}^{-1}\right)$}

Seed yield expressed in $\mathrm{Kg} / \mathrm{ha}$ was evaluated by the following formula:

$$
Y=((P \times 10000)) /(\text { S.E })
$$

where, $Y=$ dry weight of seeds in $\mathrm{Kg} / \mathrm{ha} ; P=$ dry weight of seeds per unit of experimental area; $S . E=$ Experimental surface area $\left(\mathrm{m}^{2}\right) ; 1$ ha $=10,000 \mathrm{~m}^{2}$.

\subsection{Statistical Analysis}

All data were subjected to the Analysis of Variance (ANOVA) using the Stat Graphics plus software program. Treatment means were compared using the Duncan multiple Range Test at 5\% significance. Correlations between variables were determined using the statistical package for social science (SPSS).

\section{Results and Discussion}

\subsection{Physico-Chemical Characteristics of Soils before Sowing and after Harvest}

Table 1 sumarizes the physico-chemical composition of soils prior to sowing of crops and after harvest. The soil of Sarh was sandy clay in texture, and was slightly rich in silt, nitrogen and organic matter compared to that of Ngaoundere, but the latter was rich in phosphorus with the $\mathrm{C} / \mathrm{N}$ ratio 3 folds higher than that of Sarh soil before sowing. After harvest, the soil organic matter content was reduced by about $50 \%$ in Ngaoundere-Cameroon, while at Sarh-Chad, there was a slow increase in soil organic matter content. This result suggests that the cultivation of legumes on Cameroonian soil contributed to a loss of carbon stocks following the mineralization of organic matter. This mineralization would

Table 1. Variation of the physico-chemical characteristics of experimental soils before sowing and after harvest.

\begin{tabular}{|c|c|c|c|c|c|c|c|c|c|}
\hline \multirow{3}{*}{$\begin{array}{c}\text { Parameters } \\
\text { Soil sampling } \\
\text { periods }\end{array}$} & \multicolumn{9}{|c|}{ Ngaoundere } \\
\hline & \multicolumn{3}{|c|}{ Granulometry } & \multicolumn{5}{|c|}{ Organic matter } & \multirow[b]{2}{*}{$\mathrm{pH}$} \\
\hline & $\begin{array}{l}\text { Sand } \\
(\%)\end{array}$ & Limon (\%) & $\begin{array}{l}\text { Clay } \\
(\%)\end{array}$ & Carbon (\%) & $\begin{array}{c}\text { Organic matte } \\
(\%)\end{array}$ & $\begin{array}{c}\text { Total N } \\
(\%)\end{array}$ & $\begin{array}{l}\text { Total P } \\
(\%)\end{array}$ & C/N (\%) & \\
\hline Before & $73.1 \pm 0.1^{\mathrm{a}}$ & $0.05 \pm 0.0^{\mathrm{a}}$ & $26.7 \pm 0.4^{\mathrm{b}}$ & $5,03 \pm 0^{\mathrm{a}}$ & $8.6 \pm 0.1^{b}$ & $12.1 \pm 0.3^{\mathrm{a}}$ & $21 \pm 2^{\mathrm{a}}$ & $9.8 \pm 0.1^{b}$ & 6.1 \\
\hline After & $73.9 \pm 0.4^{\mathrm{b}}$ & $0.03 \pm 0.0^{\mathrm{a}}$ & $26.0 \pm 0.1^{\mathrm{a}}$ & $5.9 \pm 02^{\mathrm{b}}$ & $4.7 \pm 09^{\mathrm{a}}$ & $14.6 \pm 0.1^{\mathrm{b}}$ & $29 \pm 0.7^{b}$ & $6.7 \pm 0.9^{\mathrm{a}}$ & 6.2 \\
\hline $\mathrm{p}$-value & 0.049 & 0.18 & 0.048 & 0.001 & $<0.0001$ & 0.0002 & 0.002 & 0.004 & \\
\hline \multicolumn{10}{|c|}{ Sarh } \\
\hline Before & $74.0 \pm 0.1^{\mathrm{a}}$ & $0.8 \pm 0.0^{\mathrm{b}}$ & $25.1 \pm 0.1^{\mathrm{b}}$ & $5.7 \pm 0.1^{\mathrm{a}}$ & $9.9 \pm 0.4^{\mathrm{a}}$ & $18.3 \pm 0.1^{\mathrm{a}}$ & $17 \pm 0.7^{\mathrm{a}}$ & $2.3 \pm 0.1^{\mathrm{a}}$ & 6.5 \\
\hline After & $75.4 \pm 0.4^{\mathrm{b}}$ & $0.4 \pm 0.1^{\mathrm{a}}$ & $24.1 \pm 0.5^{\mathrm{a}}$ & $6.3 \pm 0.0^{\mathrm{b}}$ & $10.9 \pm 0.7^{b}$ & $18.8 \pm 0.2^{\mathrm{b}}$ & $52.2 \pm 0.6^{\mathrm{b}}$ & $3.2 \pm 0.01$ & 6.7 \\
\hline p-value & 0.006 & 0.003 & 0.02 & 0.002 & 0.016 & 0.03 & $<0.0001$ & 0.002 & \\
\hline
\end{tabular}

For each granulometric or organic matter parameter in a column and within a study site, values affected by the same letter are not significantly different at the indicated level of probability. 
have been enhanced by favorable growth conditions to mineralizing bacteria present in the soil. This indicates that plants have used organic matter from the soil (Ngakou et al. [14]). The decrease in the soil organic matter content is in agreement with other results obtained in the range of between $20 \%$ and $30 \%$ (Ngakou et al. [10]). An increase of $20.66 \%$ in soil nitrogen content was observed after harvest at Ngaoundere-Cameroon compared to 3.27\% at SarhChad.

The enhanced soil $\mathrm{C} / \mathrm{N}$ ratio by $40.34 \%$ in Chad after harvest justifies the increment of carbon in the soil. The phosphorus contents were $25.88 \%$ and $38.09 \%$, respectively in Sarh and Ngaoundere soils, and this could be attributed to the presence of phosphorus solubilizing bacteria in the soil. At Sarh during harvest, soil $\mathrm{pH}$ increases towards neutrality, suggesting that free hydronium ions were fixed during the transformation of phosphorus complexes into assimilable phosphorus (Ndeye [17]; Nwaga et al. [18]).

\subsection{Effect of Cross-Inoculation on Plant Size and Biomass at 30 DAP}

At $30 \mathrm{DAP}$, groundnut plant size was improved by CR, MR and BR respectively by $5.93 \%, 17.79 \%$ and $19.49 \%$, compared to the control at Sarh (Table 2). Plants

Table 2. Plant sizes and biomasses of groundnut and Bambara groundnut as influenced by treatments at 30 days after sowing (DAS).

\begin{tabular}{ccccc}
\hline \multirow{2}{*}{ Treatements } & \multicolumn{2}{c}{ Plant sizes $(\mathrm{cm})$} & \multicolumn{2}{c}{ Plant biomasses $(\mathrm{g})$} \\
\cline { 2 - 5 } & Groundnut & Bambara groundnut & Groundnut & Bambara groundnut \\
\hline Crtl & $11.8 \pm 0.78^{\mathrm{a}}$ & $11.61 \pm 0.58^{\mathrm{a}}$ & $4.51 \pm 0.59^{\mathrm{a}}$ & $2.39 \pm 0.41^{\mathrm{a}}$ \\
GR & $11.7 \pm 1.82^{\mathrm{a}}$ & $19.64 \pm 2.28^{\mathrm{b}}$ & $5.79 \pm 1.02^{\mathrm{bc}}$ & $2.06 \pm 0.40^{\mathrm{a}}$ \\
CR & $12.5 \pm 2.50^{\mathrm{ab}}$ & $21.44 \pm 1.78^{\mathrm{cd}}$ & $5.26 \pm 1.05^{\mathrm{ab}}$ & $3.33 \pm 0.75^{\mathrm{b}}$ \\
SR & $11.3 \pm 1.15^{\mathrm{a}}$ & $22.89 \pm 1.83^{\mathrm{d}}$ & $5.64 \pm 1.27^{\mathrm{bc}}$ & $4.49 \pm 1.08^{\mathrm{c}}$ \\
BR & $14.1 \pm 1.79^{\mathrm{b}}$ & $20.83 \pm 1.81^{\mathrm{bc}}$ & $5.86 \pm 1.52^{\mathrm{bc}}$ & $3.43 \pm 0.56^{\mathrm{b}}$ \\
MR & $13.9 \pm 2.28^{\mathrm{b}}$ & $21.2 \pm 1.22^{\mathrm{c}}$ & $6.56 \pm 1.09^{\mathrm{c}}$ & $3.57 \pm 0.87^{\mathrm{b}}$ \\
p-value & 0.002 & $<0.0001$ & 0.006 & $<0.0001$ \\
& & Ngaoundere & & \\
Crtl & $13.2 \pm 0.78^{\mathrm{b}}$ & $11.55 \pm 0.76^{\mathrm{a}}$ & $7.87 \pm 1.13^{\mathrm{d}}$ & $2.13 \pm 0.42^{\mathrm{a}}$ \\
GR & $14.0 \pm 1.94^{\mathrm{bc}}$ & $14.47 \pm 1.74^{\mathrm{b}}$ & $5.33 \pm 0.64^{\mathrm{b}}$ & $1.57 \pm 0.35^{\mathrm{a}}$ \\
CR & $14.6 \pm 0.84^{\mathrm{c}}$ & $19.85 \pm 1.71^{\mathrm{c}}$ & $6.41 \pm 1.22^{\mathrm{c}}$ & $3.33 \pm 0.77^{\mathrm{bc}}$ \\
SR & $14.2 \pm 0.91^{\mathrm{bc}}$ & $19.78 \pm 0.81^{\mathrm{c}}$ & $6.26 \pm 0.76^{\mathrm{c}}$ & $3.12 \pm 0.39^{\mathrm{b}}$ \\
BR & $14.2 \pm 0.78^{\mathrm{bc}}$ & $21.78 \pm 1.08^{\mathrm{d}}$ & $5.71 \pm 0.67^{\mathrm{bc}}$ & $3.70 \pm 0.97^{\mathrm{c}}$ \\
MR & $11.7 \pm 1.15^{\mathrm{a}}$ & $20.03 \pm 0.97^{\mathrm{c}}$ & $4.14 \pm 0.28^{\mathrm{a}}$ & $3.15 \pm 0.56^{\mathrm{bc}}$ \\
p-value & 0.0001 & 0.0001 & 0.0001 & 0.02 \\
\hline
\end{tabular}

For each parameter in a column, values affected by the same letter are not significantly different at the indicated level of probability. GR: Groundnut Rhizobia, CR: Cowpea Rhizobia, SR: Soybean Rhizobia, BR: Bambara groundnut Rhizobia, MR: mélange des quatre Rhizobia. 
inoculated with $B R, M R$ were significantly taller $(p=0.002)$ than those inoculated with GR, SR and uninoculated plants. The size of plant treated with cowpea rhizobia was significantly higher $(\mathrm{p}<0.0001)$ than that of plant treated MR, as well as the control plants at 30 DAP in Ngaoundere.

Inoculation of Bambara groundnut plants with rhizobia accelerated their growth height (Table 2) at $30 \mathrm{DAP}$. This increment in plant size varied from $69.16 \%$ to $97.15 \%$ compared to that of untreated plants at Sarh. The size of plants treated with SR was more important than that of other treatments. This suggests that these bacteria may have contributed to the production of growth hormones that have accelerated the plant growth in size. Inoculation of cowpea plants with two strains of rhizobia was revealed to greatly increase the stem size (Abed Nour el Houda [19]). Results obtained from this study line with other findings which reported plant size ranging from between 20 and $38 \mathrm{~cm}$ depending on the seed varieties used (Ndiang et al. [20]).

At Ngaoundere, inoculation of Bambara groundnut with nitrogen-fixing bacteria resulted in a considerable improvement in plant size (Table 2) at $30 \mathrm{DAP}$, from between $25.28 \%$ and $88.57 \%$ compared to untreated plants. Plants treated with BR significantly have greater size $(\mathrm{p}=0.0001)$ than plants of other treatments. This result is above those pointed out from a research performed in Adamawa (Gomoung [21]). Inoculation of Bambara groundnut with rhizobia and mycorrhiza was claimed to positively improve the plant biomass (Ngakou et al. [14]). The positive effect of inoculum on plant size can be explained by the production of plant growth hormones such as auxin and gibberellins (Vargas et al. [22]). In a related research, soybean inoculated with Bradyrhizobium strain was revealed to exhibit greater biomass than non-inoculated plants through AIA production by bacteria symbiont (Afzal et al. [23]).

\subsection{Effect of Cross-Inoculation on Plant Biomass at 30 DAP}

The use of the inoculum significantly improved $(\mathrm{p}=0.006)$ the plant biomass of groundnut plant at Sarh (Table 2). The biomass of inoculated plants was more elevated and varied from $16.62 \%$ in $\mathrm{CR}$ to $45.45 \%$ in MR treated compared to that of uninoculated plants. The enhanced plant biomass was reported to be attributed to soils nutrient improvement by symbiotic bacteria (Ama-Abina et al. [24]). At Ngaoundere, the plant biomass of untreated groundnut plants was significantly $(\mathrm{p}=0.0001)$ higher than that of inoculated plants, indicating that indigenous rhizobia were more efficients on groundnut than in introduced strains. However, plants inoculated with CR and SR had higher dry biomass than those inoculated with GR and MR.

At Sarh, the most important Bambara groundnut plant biomass at 30 DAP was obtained from SR-inoculated plants. There was a highly significant difference between the biomass of CR, BR, MR, SR treated plants (Table 2). The inoculum improved the Bambara groundnut biomass from $39.33 \%$ to $87.86 \%$ as compared to that of the control. GR did not affect in anyway the Bambara groundnut biomass. This result lines with another finding which yielded an av- 
erage biomass of $5 \mathrm{~g}$ per plant (Ngakou et al. [14]).

At Ngaoundere rhizobia inoculum moderately improved the groundnut plants biomass (Table 2). BR treatment contributed to $73.70 \%$ improvement of biomass as compared to the control. There was a positive and significant correlation $(\mathrm{r}=0.63, \mathrm{p}=0.0001)$ between the size and Bambara groundnut biomass.

\subsection{Changes in Number and Pods Weight per Plant in Response to Cross-Inoculation}

\subsubsection{Pod Number}

Results from Table 3 indicate that the number of pods (104 pods) per CR- inoculated groundnut plant was significantly greater $(\mathrm{p}<0.0001)$ than that of other treatments at Sarh. Inocululation improved groundnut pod yield of all plants inoculated with rhizobia. This pods number per plant was superior to the range of between 28 and 37 pods per plant obtained in some uninoculated groundnut varieties during the rainfall cropping seasons (Betdogo et al. [25]).

At Ngaoundere, the number of pods per individual inoculated groundnut plant $(76)$ was higher $(\mathrm{p}<0.0001)$ than in plants treated with $C R, B R$, and MR. A significant difference $(p=0.0001)$ was observed between the number of pods

Table 3. Number and dry weight of pods per Bambara groundnut and groundnut plants as influence by different rhizobia inoculation receipts at Ngaoundere-Cameroon and SarhChad.

\begin{tabular}{ccccc}
\hline & \multicolumn{2}{c}{ Number of pod/plant } & \multicolumn{2}{c}{ Dry weight of pods/plant (g) } \\
\hline Treatements & Groundnut & Bambara groundnut & Groundnut & Bambara groundnut \\
\hline & & Sarh & & \\
Crtl & $68.86 \pm 10.14^{\mathrm{a}}$ & $19.2 \pm 1.65^{\mathrm{a}}$ & $36.51 \pm 6.25^{\mathrm{a}}$ & $16.05 \pm 0.91^{\mathrm{b}}$ \\
GR & $88,8 \pm 5.59^{\mathrm{c}}$ & $20.4 \pm 4.23^{\mathrm{ab}}$ & $48.49 \pm 8.49^{\mathrm{b}}$ & $16.50 \pm 3.13^{\mathrm{bc}}$ \\
CR & $104.4 \pm 15.78^{\mathrm{d}}$ & $23.26 \pm 5.93^{\mathrm{b}}$ & $64.07 \pm 7.74^{\mathrm{c}}$ & $15.22 \pm 3.79^{\mathrm{b}}$ \\
SR & $77.6 \pm 10.56^{\mathrm{b}}$ & $21.93 \pm 4.41^{\mathrm{ab}}$ & $43.93 \pm 7.92^{\mathrm{b}}$ & $14.93 \pm 3.83^{\mathrm{b}}$ \\
BR & $79.13 \pm 11.00^{\mathrm{b}}$ & $30.4 \pm 6.68^{\mathrm{c}}$ & $45.69 \pm 7.12^{\mathrm{b}}$ & $18.52 \pm 3.61^{\mathrm{c}}$ \\
MR & $82.66 \pm 12.57^{\mathrm{bc}}$ & $20.4 \pm 3.52^{\mathrm{ab}}$ & $46.73 \pm 7.02^{\mathrm{b}}$ & $11.11 \pm 3.38^{\mathrm{a}}$ \\
p-value & $<0.0001$ & $<0.0001$ & $<0.0001$ & $<0.0001$ \\
& & Ngaoundere & & \\
Crtl & $70.93 \pm 11.67^{\mathrm{b}}$ & $13.13 \pm 3.62^{\mathrm{a}}$ & $45.88 \pm 9.15^{\mathrm{b}}$ & $6.66 \pm 1.69^{\mathrm{a}}$ \\
GR & $76.73 \pm 13.15^{\mathrm{b}}$ & $16.6 \pm 2.92^{\mathrm{b}}$ & $44.29 \pm 8.95^{\mathrm{b}}$ & $10.85 \pm 3.08^{\mathrm{b}}$ \\
CR & $56.4 \pm 17.27^{\mathrm{a}}$ & $23.6 \pm 4.48^{\mathrm{c}}$ & $34.42 \pm 7.84^{\mathrm{a}}$ & $14.88 \pm 3.38^{\mathrm{c}}$ \\
SR & $75.2 \pm 16.65^{\mathrm{b}}$ & $12.0 \pm 2.90^{\mathrm{a}}$ & $44.15 \pm 16.89^{\mathrm{b}}$ & $6.45 \pm 1.92^{\mathrm{a}}$ \\
BR & $54.33 \pm 11.72^{\mathrm{a}}$ & $16.73 \pm 3.34^{\mathrm{b}}$ & $38.48 \pm 9.65^{\mathrm{ab}}$ & $11.29 \pm 2.69^{\mathrm{b}}$ \\
MR & $46.46 \pm 14.16^{\mathrm{a}}$ & $11.0 \pm 3.02^{\mathrm{a}}$ & $31.56 \pm 5.65^{\mathrm{a}}$ & $7.53 \pm 1.61^{\mathrm{a}}$ \\
p-value & $<0.0001$ & 0.0001 & 0.0005 & 0.0001 \\
\hline
\end{tabular}

For each parameter in a column, values affected by the same letter are not significantly different at the indicated level of probability. GR: Groundnut Rhizobia, CR: Cowpea Rhizobia, SR: Soybean Rhizobia, BR: Bambara groundnut Rhizobia, MR: mélange des quatre Rhizobia. 
of non-inoculated plants and the plants inoculated with CR. This enhanced number of pods could be attributed to efficient wild rhizobia strains that would have interacted rapidly with the host plant, while the introduced inoculants were less competitive. The high content of organic matter in the soil could have also accounted for these poor performances of rhizobial inoculant. These results line with other results reported from which the presence of straw compost attenuated the effect of the inoculum (Ndiaye [26]). Inoculation enhanced the number of Bambara groundnut pods per plant at Sarh by $58.33 \%$ over the control. These results are lower than those reported in Bambara groundnut dual inoculated with rhizobia and mycorhiza in the field (Yao et al. [27]), and may be attributed to high soil moisture during pods formation as previously pointed out (Ameyaw and Doku [28]).

At Ngaoundere, the number of Bambara groundnut pods per plant (23) was higher in the CR-inoculated plants than in other treatments. The pods number was improved by $79.74 \%$ over the control.

\subsubsection{Pods Dry Weight}

The pod dry weight of groundnut plants inoculated with CR was higher than that of the control at Sarh. Inoculants improved the pod dry weight by $20.32 \%$ to $75.48 \%$ relative to untreated pods. The dry weight of pods was twice the one obtained in Senegal after seed inoculation with selected bacteria combined to phosphorus-gypsium intake (Dhery and Dreyfus [29]).

At Ngaoundere the dry weight of groundnut pods per plant was higher $(\mathrm{p}=$ 0.0005) in plants inoculated with GR, SR and untreated plants than in plants treated with CR and MR (Table 3). This high dry weight of pods of untreated plants was due to the fact that some pods were filled with soil, confirming what was previously reported (Gomoung [21]). The increase in the number of pods per plant positively impacted the dry weight of pods per groundnut plant, implying a positive and significant correlation $(r=0.28, p=0.006)$ between the two parameters.

The dry weight of Bambara groundnut pods per plant varied with treatments at Sarh-Chad ranging from $11.1 \mathrm{~g}$ to $18.52 \mathrm{~g}$ depending on the treatment (Table 3). The decrease pods dry weight of Bambara groundnut in MR inoculated plants compared to that of the control was attributed the fact that some mature pods were not filled with seeds. Pod full containing seeds would depend not only on the instantaneous supply of carbon and nitrogen, but also the remobilization from the vegetative organs. The newly accumulated exogenous nitrogen was thus not sufficient to satisfy the high seeds requirements, and their growth rate then became metabolically associated with nitrogen remissions (Salon et al. [30]). The pods dry weight of Bambara groundnut per plant was important in the RR treatment (Table 3) with $14.88 \mathrm{~g}$ per plant at Ngaoundere, the lowest dry weight accounting for SR-inoculated pods. Increasing the pods dry weight would have involved other factors such as pod size, pod filling in seed, and number of seeds per pod. 


\subsection{Variation of Seed Yield (kg.ha-1) of Groundnut and Bambara Groundnut in Response to Cross-Inoculation with Different Rhizobia Strains}

Seed yield $\left(\mathrm{kg} \cdot \mathrm{ha}^{-1}\right)$ of rhizobia inoculated groundnut was improved from $9.83 \%$ to $63.73 \%$ compared to the control at Sarh (Figure 1(a)). The highest yield was obtained from CR treated plants. This result was favored by the improvement of soil fertility through atmospheric nitrogen fixation (Dey et al. [31]), and the solubilization of soil phosphorus by specific rhizobia, making it available for the host plant (Andriamananjara [32]). In pure culture, inoculation of plant with Rhizobium was claimed to be an alternative to improve plant growth and productivity (Diop et al. [33]).

At Ngaoundere, the enhanced seed yield in groundnut inoculated treatments was attributed either to improvement of soil fertility through atmospheric

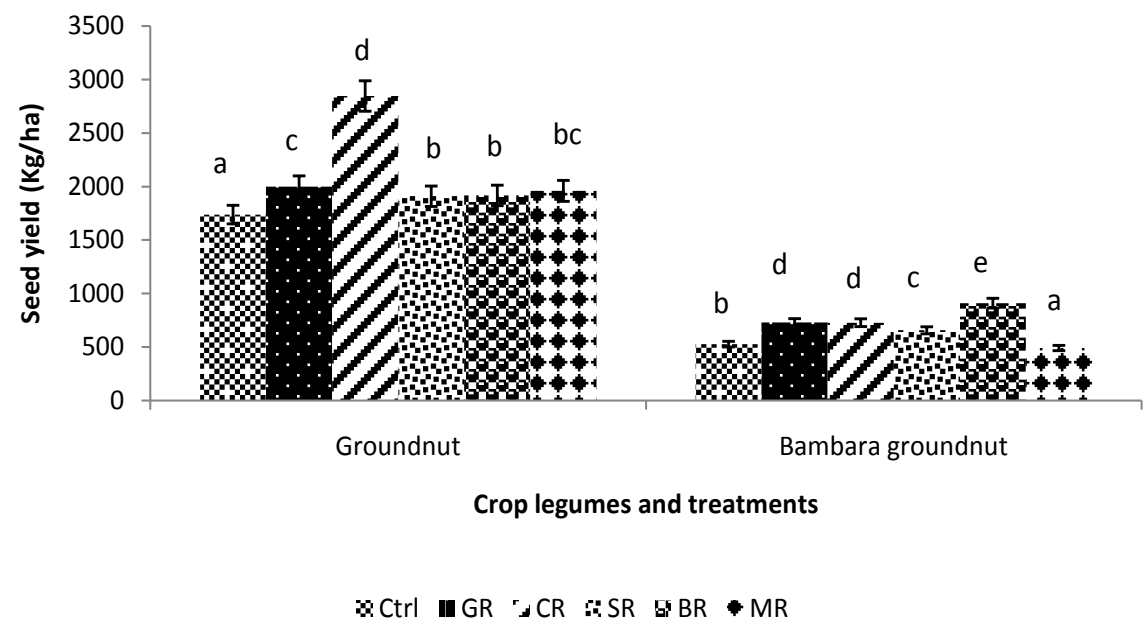

(a)

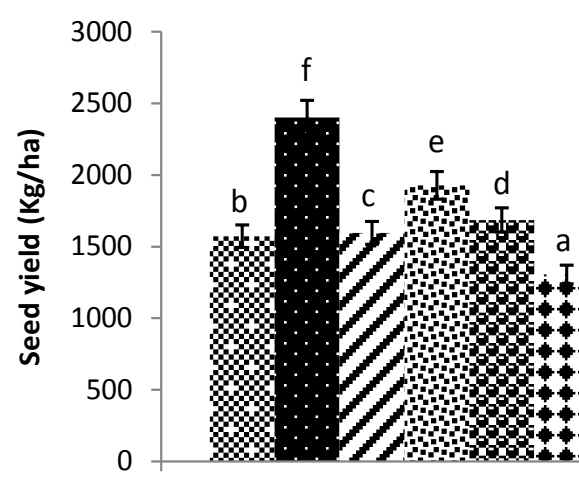

Groundnut

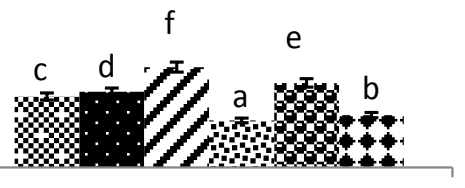

Bambara groundnut

Crop legumes and treaitments

$\& \operatorname{Ctrl} \cdot \mathrm{GR} \leadsto \mathrm{CR}$ : $\mathrm{SR} \approx \mathrm{BR} \bullet \mathrm{MR}$

(b)

Figure 1. Variation of seed yield of groundnut and Bambara groundnut kg/ha at at SarhChad (a); and Ngaoundere-Cameroon (b). For each of the plant species, bars affected by the same letter are not significantly different at the level of probability indicated. 
nitrogen fixation (Badawi et al. [34]), or the soil phosphorus solubilizing rhizobia (Mekhemar et al. [35]). Other reported results have indicated seed yield of between $975 \mathrm{~kg} \cdot \mathrm{ha}^{-1}$ and $1.432 \mathrm{t} \cdot \mathrm{ha}^{-1}$ (Ndiaye [26]), bellow our findings. Seed yield per hectare of untreated plants $\left(1.57 \mathrm{t} \cdot \mathrm{ha}^{-1}\right)$ was found to be statistically equal to the average pod yield $\left(1.63 \mathrm{t} \cdot \mathrm{ha}^{-1}\right)$ of five cultivars of groundnuts introduced into northern Cameroon (Betdogo et al. [25]).

Results on Figure 1 indicate that Bambara groundnut seed yield was in the range between 491.25 and $910.375 \mathrm{~kg} \cdot \mathrm{ha}^{-1}$ depending on the treatments at Sarh. The performance of the BR treatment was greater $(\mathrm{p}<0.0001)$ than that of the control. BR improved the seed yield of Bambara groundnut by $72.71 \%$. These results are in agreement with recent findings which reported yield values varying between 300 to $800 \mathrm{~kg} \cdot \mathrm{ha}^{-1}$ (Brink [36]), or between $524.25 \mathrm{~kg}$ and $912.1 \mathrm{~kg} \cdot \mathrm{ha}^{-1}$ in Bambara groundnut dually inoculated in the field with rhizobia and mycorhiza (Ngakou et al. [14]), but are twice those from which seed yield of between 130 to $470 \mathrm{~kg} \cdot \mathrm{ha}^{-1}$ in was obtained (Salon et al. [30]).

The highest seed yield was that of CR treatment $\left(699.77 \mathrm{~kg} \cdot \mathrm{ha}^{-1}\right)$, whereas the lowest was observed (Figure 1(b)) in SR treatment (327.26 kg.ha ${ }^{-1}$ ) at Ngaoundere. Rhizobial inoculation at sowing was reported to increases seed dry weight and yield (Mnasri et al. [37]). This yield increment was attributed to the improvement in mineral nutrition of plants, as well as seeds content in $\mathrm{N}$ and $\mathrm{P}$, following inoculation (Ngakou et al. [12]). Similar to our findings, grain yield varying from 485 to $1322 \mathrm{~kg} \cdot \mathrm{ha}^{-1}$ depending on Bambara groundnut varieties has been reported (Pungulani et al. [38]).

\subsection{Links between the Yield Parameters}

The affinity between yield parameters of each studied crop was express through the Pearson correlation (Table 4). A positive and significant correlation $(r=0.5$, $\mathrm{p}<0.0001$ ) was detected between the number of seeds and the dry weight of the pods at Ngaoundere. At Sarh, the correlation between the number and dry weight of pods was positive and highly significant $(r=0.55, p<0.0001)$. Similarly, the the pod weight highly and significant correlated $(\mathrm{r}=0.59, \mathrm{p}<0.0001)$ with the number seeds per pod on the same site. On the overall, all the yield parameters within each of the studied site positively and significantly correlated each other.

\section{Conclusion}

This study has indicated that cross-inoculation did contribute to improve soil fertility (nitrogen and phosphorus content) and yield of groundnut and Bambara groundnut in the field. Improved seed yield expressed in $\mathrm{kg} / \mathrm{ha}$ varied from 9.83 to $63.73 \%$ in groundnut, and to $72.71 \%$ in Bambara groundnut. These results suggest that groundnut and Bambara groundnut have a symbiotic affinity with rhizobia from other legume crop species. Mixture of Rhizobium from several crop legume species may not be indicated for Bambara groundnut, whereas GR, $\mathrm{CR}, \mathrm{SR}, \mathrm{BR}$ and MR could be used to improve seed yield of groundnuts. For 
Table 4. Correlation between yield parameters of the two crop legumes.

\begin{tabular}{|c|c|c|c|}
\hline Crop legumes & Parameters & Correlations (p-values) & Study sites \\
\hline \multirow{12}{*}{ Groundnut } & Pods number-pods weight & $0.558(<0.0001)$ & Sarh \\
\hline & Pods number-seeds number & $0.526(<0.0001)$ & Sarh \\
\hline & Pods number-seeds weight & $0.486(<0.0001)$ & Sarh \\
\hline & Pods weight-seeds number & $0.59(<0.0001)$ & Sarh \\
\hline & Pods weight-seeds weight & $0.567(<0.0001)$ & Sarh \\
\hline & Seeds weight-seeds number & $0.559(<0.0001)$ & Sarh \\
\hline & Pods number-pods weight & $0.289(0.006)$ & Ngaoundere \\
\hline & Pods number-seeds number & $0.258(0.014)$ & Ngaoundere \\
\hline & Pods number-seeds weight & $0.486(<0.0001)$ & Ngaoundere \\
\hline & Pods weight-seeds number & $0.333(0.001)$ & Ngaoundere \\
\hline & Pods weight- seeds weight & $0.210(0.047)$ & Ngaoundere \\
\hline & Seeds weight-seeds number & $0.302(0.004)$ & Ngaoundere \\
\hline \multirow{11}{*}{ Bambara groundnut } & Pods number-seeds number & $0.323(0.002)$ & Sarh \\
\hline & Pods number-seeds weight & $0.484(<0.0001)$ & Sarh \\
\hline & Pods weight-seeds number & $0.428(<0.0001)$ & Sarh \\
\hline & Pods weight-seeds weight & $0.454(<0.0001)$ & Sarh \\
\hline & Seeds Number-seeds weight & $0.432(<0.0001)$ & Sarh \\
\hline & Pods number-pods weight & $0.585(<0.0001)$ & Ngaoundere \\
\hline & Pods number-seeds number & $0.511(<0.0001)$ & Ngaoundere \\
\hline & Pods number-seeds weight & $0.641(<0.0001)$ & Ngaoundere \\
\hline & Pods weight-seeds number & $0.50(<0.0001)$ & Ngaoundere \\
\hline & Pods weight-seeds weight & $0.675(<0.0001)$ & Ngaoundere \\
\hline & Seeds Number-seeds weight & $0.384(<0.001)$ & Ngaoundere \\
\hline
\end{tabular}

large-scale and sustainable agricultural production, it would be imperative to produce these inoculants in solid form and make them available to farmers.

\section{Acknowledgements}

The authors are thankful to all those who, in one way or the other, have contributed to the improvement and proof-reading of this manuscript. The financial support of the University of Sarh-Chad allocated to $\mathrm{PhD}$ students within the training of trainers program is particularly appreciated.

\section{References}

[1] Bado, B.V. (2002) Role of Legume on the Fertilization of Tropical Ferruginous Soils in the Guinean and Sudanian Zones of Burkina Faso. Ph.D. Thesis, University of Laval Quebec, Canada.

[2] Freeman, E., Jackie, H., Queteen, M., Saye, J. and Bushop, J. (2001) Multipurpose Vegetable-Based Rotation to Improve Soil Fertility and Profitability of Garden 
Fields. Ciespla New Letter, 7, 4-5.

[3] Cooke, R.D. (1998) Food Insecurity in ACP Countries: Policies and Programs of Interventions to Vulnerable Groups. Synthesis Report and Recommendation of the Seminar of the CTA University of Louvain, Belgium.

[4] Acosta, J.A.A., Amado, T.J.C., Neergaard, A., Vinther, M., Silva, L.S. and Nicoloso, R.S. (2011) Effect of 15N-Labeled Hairy Vetch and Nitrogen Fertilization on Maize Nutrition and Yield under No Tillage. Revista Brasileira de Ciencia do Solo, 35, 1337-1345. https://doi.org/10.1590/S0100-06832011000400028

[5] Tien, H.H., Hien, T.M., Her, M.T. and Herridge, D. (2002) Inoculation and $\mathrm{N}_{2}$ Fixation of Soybean and Mungbean in the Eastern Region of South Vietnam. 109th Proceedings (ACIAR) Inoculants and Nitrogen at Vegetables in Vietnam, Hanoi, 17-18 February 2001, 29-36.

[6] Watier, B.A. (1982) Balanced Diet in Africa. How? In: Hoffman-La Roche et Cie, F., Ed., Neuilly-sur-Seine, Paris, 30.

[7] Ahmet, G.M. and Abdallah, A. (2010) Nutritive Evaluation of Bambara Groundnut (Vigna subterranea) Pods, Seeds and Hull as Animal Feeds. Journal of Applied Science Research, 6, 383-386.

[8] Gandbe, M., Ngakou, A., Amougou, T.I. and Amougou A.F. (2010) Altering the Time of Intercropping Cowpea (Vigna unguiculata (L.) Walp.) Relative to Maize (Zea mays L.): A Food Production Strategy to increase Crop Yield Attributes in Adamawa-Cameroon. World Journal Agricultural Sciences, 6, 473-479.

[9] Useni, S.Y., Mayele, K., Kasangij, A.K.P., Nyembo, K.L. and Baboy, L.L. (2014) Effect of Sowing Date and Gauge on Growth and Yield of Cowpea (Vigna unguiculata L. Walp) in Lubumbashi, Democratic Republic of the Congo (DRC). International Journal of Innovation and Applied Studies, 6, 40-47.

[10] Ngakou, A., Koehler, H. and Ngueliaha, H.C. (2014) The Role of Cow Dung and Kitchen Manure Composts and Their Non-Aerated Compost Teas in Reducing the Incidence of Foliar Diseases of Lycopersicon esculentum (Mill). International Journal of Agricultural Research, Innovation and Technology, 4, 88-97. https://doi.org/10.3329/ijarit.v4i1.21100

[11] Ridine, W., Ngakou, A., MBaïguinam, M., Namba, F. and Pataï, A. (2014) Interactive Effects of Chemical (NPK) and Organic (Bat Guano) Fertilizers on Two Selected Maize Varieties Grown in Pala (Chad). Pakistan Journal of Botany, 46, 1673 1770 .

[12] Ngakou, A., Nwaga, D., Ntonifor, N.N., Tamo, M., Nebane, C.L.N. and Parh, I.A. (2007) Contribution of Arbuscular Mycorrhizal Fungi (AMF), Rhizobia and Metarhizium anisopliae to Cowpea Production in Cameroon. International Journal of Agricultural Research, 2, 754-764. https://doi.org/10.3923/ijar.2007.754.764

[13] Ngakou, A., Moctar, M., Njintang, Y.N. and Tamò, M. (2011) Some Cowpea Quality Seed Indicators as Influenced by Field Application of Selected Biofertilizers and Mycoinsecticide in Three Agroecological Zones of Cameroon. Communication in Soil Science and Plant Analysis, 42, 1277-1289. https://doi.org/10.1080/00103624.2011.571738

[14] Ngakou, A., Ngo Nkot, L., Gomoung, D. and Adamou, S. (2012) Mycorrhiza- Rhizobium-Vigna Subterranea Dual Symbiosis: Impact of Microbial Symbionts for Growth and Sustainable Yield Improvement. International Journal of Agriculture and Biology, 14, 915-921.

[15] AFNOR (French Association of Normalization) (1982) Collection of French Norms of Products Derived from Fruits and Legumes: Fruits Juice. Paris, 327.

[16] Zakaria, K., Pauline, B.K., Romaric, K.N., Mahamadou, S. and Jean-Didier, Z. (2015) The Agro-Morphological Characterization of the White Caya (Cleome gy- 
nandra L.) of Western Burkina Faso. International Journal of Innovation and Applied Studies, 11, 156-166.

[17] Ndeye, F.D. (2002) Use of Rhizobium Inoculum for the Cultivation of Beans (Phaseolus vulgaris) in Senegal. Doctoral Thesis, Cheikh Anta Diop Dakar University, Faculty of Science and Technology, Department of Plant Biology, 112 p.

[18] Nwaga, D., Ambassa-Kiki, R. and Nsangou, M.L. (2003) Response of Cowpea ( Vigna unguiculata, Leguminosae) to Inoculation by Rhizobia and Mycorrhizal Fungi in Field on Ferralitic Soil in Southern Cameroon. Annal of the Faculty of Sciences, University of Yaounde I. Series: Science of Nature and Life, 35, 34-40.

[19] Abed Nour el, H. (2011) Effect of Inoculation on the Growth and Yield of Vigna unguiculata (L.) Walpers under Saline Stress. Memory of Magister. Faculty of Science, University of Oran, Bordeaux.

[20] Ndiang, Z., Bell, J.M., Missoup, A.D., Fokam, P.E. and Amougou, A. (2012) A Study of the Morphological Variability of Some Varieties of Bambara Groundnut (Vigna subterranea (L.) Verdc) in Cameroon. Journal of Applied Biosciences, 60, 44104420 .

[21] Gomoung, D. (2011) Responses of the Bambara Groundnut (Vigna subterranea (L.) Verdc.) to the Double Inoculation Rhizobium and Mycorrhizae in Dang Ngaoundéré. Master Thesis, Department of Biological Sciences, Faculty of Sciences, University of Ngaoundere, $53 \mathrm{p}$.

[22] Vargas, L.K., Lisboa, B.B., Giongo, A., Beneduzi, A. and Luciane, P. (2010) Passaglia. Potential of Rhizobia as Plant Growth-Promoting Rhizobacteria. In: Khan S., et al., Eds., Microbes for Legume Improvement, Springer-Verlag, Berlin, 137-157. https://doi.org/10.1007/978-3-211-99753-6_7

[23] Afzal, A., Asghari, B. and Mussarat, F. (2010) Higher Soybean Yield by Inoculation with N-Fixing and P-Solubizing Bacteria. Agronomy for Sustainable Development, 30, 487-495. https://doi.org/10.1051/agro/2009041

[24] Ama-Abina, T.J., Beugre, G.F., N’gbesso, M.F.P., N’Guessan, D.B. and Yoro, G.R. (2012) Effects of a Herbicide and Inoculation on the Yield Factors of Soybeans Grown on Gravelly Topsoil. Intternational Journal of Biological and Chemical Science, 6, 1970-1978.

[25] Betdogo, S., Sali, B., Adamou, I. and Woin, N. (2015) Agronomic Evaluation of Five Cultivars of Groundnuts (Arachis hypogeae L.) Introduced in the Northern Cameroon Region. Journal of Applied Biosciences, 89, 8311-8319. https://doi.org/10.4314/jab.v89i1.5

[26] Ndiaye, M. (1986) Contribution to Bacterial Inoculation in the Field of Groundnut (Arachis-Hypogaea) and Soybean (Glycine max) in Senegal. Dakar-Senegal.

[27] Yao, D., Bonny, B. and Ire Zoro Bi, A. (2005) Biotechnology, Agronomy, Preliminary Observation of the Variability between Some Morphotypes of Ivory Coast (Vigna subterranea L. verdc., Fabaceae). Biotechnology, Agronomy, Society and Environment, 9, 249-258.

[28] Ameyaw, G.C.E. and Doku, E.V. (1983) Effect of Soil Moisture Stress on the Reproductive Efficiency and Yield of the Bambara Groundnut (Vigna subterranea). Crop Science, 28, 23-29.

[29] Dhery, M. and Dreyfus, B. (1991) Three Recommended Treatments for the Cultivation of Groundnuts in Senegal: Denematisation, Seed Inoculation by Selected Rhizobia and Phosphorus-Gypsum Intake. Oleaginous, 46, 197-207.

[30] Salon, C., Munier-Jolain, N., Duc, G., Voisin, A.S., Grandgirard, D., Larmure, A., Emery, R. and Ney, B. (2001) Grain Legume Seed Filling in Relation to Nitrogen Acquisition: A Review and Prospects with Particular Reference to Pea. Agronomy, 
EDP Sciences, 21, 539-552.

[31] Dey, R., Pal, K.K., Bhatt, D.M. and Chauhan, S.M. (2004) Growth Promotion and Yield Enhancement of Peanut (Arachis hypogaea L.) by Application of Plant GrowthPromoting Rhizobacteria. Microbiology and Biological Researche, 159, 371-394.

[32] Andriamananjara, A. (2011) Vouandzou-Rainfed Rice (Oryza sativa) Rotation System in the Highlands of Madagascar. Role of Voandzou (Vigna subterranea) on the Bioavailability of Phosphorus in Ferralsols. Doctoral Thesis, School of Agronomic Sciences (ESSA) University of Antananarivo, Madagascar.

[33] Diop, I., Aboubacry, K., Tatiana, K.W., Kadidia, B.S., Pascal, H. and Kandioura, M.N. (2013) The Impact of Pedoclimatic and Crop Conditions on the Response of Cowpea (Vigna unguiculata L. Walp.) to Endomycorrhizal Inoculation with Rhizophagus irregularis. Journal of Applied Biosciences, 69, 5465-5474.

https://doi.org/10.4314/jab.v69i0.95072

[34] Badawi, F.Sh.F., Biomy, A.M.M. and Desoky, A.H. (2011) Peanut Plant Growth and Yield as Influenced by Co-Inoculation with Bradyrhizobium and Some Rhizo- Microorganisms under Sandy Loam Soil Conditions. Annal of Agricultural Science, $56,17-25$.

[35] Mekhemar, G.A.A., Ismail, F.M., Badawi, F.Sh.F. and Kandil, B.A.A. (2007) Response of Peanut (Arachis hypogaea L.) to Co-Inoculation with Bradyrhizobium spp. and Phosphate Dissolving Bacteria under Different Levels of Phosphorus Fertilization in Sandy Soils. Agricultural Research Journal, Suez Canal Univiversity, 7, $1-8$.

[36] Brink, M., Ramolemana, G.M. and Sibuga, K.P. (2006) Vigna subterranea (L) Verd. In: Brink, M. and Belay, G., Eds., PROTA 1: Cereals and Pulses/Cereals and Pulses, PROTA, Wageningen, 241-246.

[37] Mnasri, B., Fatma, T.A., Mustapha, T.R., Mohamed, E.A.O. and Ridha, M.H. (2007) Rhizobium gallicum as an Efficient Symbiont for Bean Cultivation. Agronomy Sustainable Development, 27, 331-336. https://doi.org/10.1051/agro:2007024

[38] Pungulani, L., Davie, K., Lucius, N. and Modester, K. (2012) Selection of High Yielding and Preferred Genotypes of Bambara Nut (Vigna subterranea (L.) Verdc) in Malawi. American Journal of Plant Science, 3, 1802-1808.

https://doi.org/10.4236/ajps.2012.312A221

Scientific Research Publishing

Submit or recommend next manuscript to SCIRP and we will provide best service for you:

Accepting pre-submission inquiries through Email, Facebook, LinkedIn, Twitter, etc. A wide selection of journals (inclusive of 9 subjects, more than 200 journals)

Providing 24-hour high-quality service

User-friendly online submission system

Fair and swift peer-review system

Efficient typesetting and proofreading procedure

Display of the result of downloads and visits, as well as the number of cited articles

Maximum dissemination of your research work

Submit your manuscript at: http://papersubmission.scirp.org/

Or contact ajps@scirp.org 